IRSTI 82.15.09

\author{
Tashpulatov Sh. ${ }^{1}$, Kupeshova S. ${ }^{2}$, Meirkhanova Y. ${ }^{3}$ \\ ${ }^{1} \mathrm{PhD}$, Czech Technical University, Czech, Prague, e-mail: stashpul@cerge-ei.cz \\ ${ }^{2}$ c.e.s., associate professor, e-mail: s.kupeshova@mail.ru \\ ${ }^{3}$ Doctoral student, e-mail: yerkezhan.meirkhanova@gmail.com \\ ${ }^{2,3}$ Al-Farabi Kazakh National University, Kazakhstan, Almaty

\section{PRACTICE AND FORMATION MODELS OF PROFESSIONAL ORIENTATION OF SCHOOLCHILDREN}

The lack of demand on fresh graduates on the labor market and inability to interact under conditions of market relations is one of the acute problems among young generation. Life requires the ability to choose the sphere of his professional and labor activity, focusing on the needs of society and taking into account the prospects of material well-being as well as individual and personal development, i.e. ability of professional self-determination. However, the education system is not ready to provide effective assistance to high school students in choosing a profession, since the content of professional self-determination as the goal of education has not been clarified from the perspective of governmental program, there is no scientific and pedagogical foundations, professional self-determination have not been developed in terms of updating the national school.

Most of the problems of professional self-determination are investigated mainly within the framework of vocational guidance, which is often regarded as an object, rather than a means of scientific management. The main goal of the article is to cope with the use of a generalized model of choosing a profession without taking into account the individual characteristics of a high school student, the lack of a differentiated approach to students with different levels of readiness for professional self-determination, as well as informational supply in the world of professions.

These circumstances make it necessary to develop a dynamic model for the development of professional self-determination for senior schoolchildren.

During the research it was found that up-to-date graduates need to "to try on", that is, it is important to make them familiarize with profession's 'demo-version' before making a final decision. This allows us to offer more active project activities for high school students, as well as considering the possibility of short-term internships or entity visits for graduates.

Key words: professional orientation, project management, high schools, career building.

$$
\begin{aligned}
& \text { Ташпулатов Ш. }{ }^{1}, \text { Купешова С. }{ }^{2}, \text { Мейрханова E. }{ }^{3} \\
& { }^{1} \mathrm{PhD}, \text { Чех техникалық университеті, Чехия, Прага қ., е-mail: stashpul@cerge-ei.cz } \\
& { }^{2} \text { э.ғ.к., доцент, e-mail: s.kupeshova@mail.ru } \\
& { }^{3} \text { Аокторант, e-mail: yerkezhan.meirkhanova@gmail.com } \\
& \text { 2,3əл-Фараби атындағы Қазақ ұлттық, университеті, Қазақстан, Алматы қ. } \\
& \text { Мектеп оқушыларының кәсіптік бейімдекуінің } \\
& \text { тәжірибесі мен модельдері }
\end{aligned}
$$

Еңбекнарығындағыжастардыңсұранысыныңболмауы,нарықтыққатынастаржағдайындаөзара әрекеттесудің өзектілігі қазіргі заманғы Қазақстанның күрделі мәселелерінің бірі болып табылады. Мектеп бітірушісі кәсіби және еңбек қызметінің саласын таңдап, қоғам қажеттіліктеріне назар аударады және материалдық тұрмыс жағдайын ғана емес, сондай-ақ, жеке дамуды да ескереді, Аемек кәсіби өзін-өзі анықтау қабілеті маңызды болады.

Алайда, білім беру жүйесі орта мектептің оқушыларына мамандық таңдауда тиімді көмек көрсетуге дайын емес, себебі кәсіби өзін-өзі танудың мазмұны білімнің мақсаты ретінде заманауи тұрғылан анықталмаған және кәсіби өзін-өзі анықтаудың ғылыми-педагогикалық, негіздері ұлттық, мектептің жаңаруы тұрғысынан дамымаған. 
Кәсіби өзін-өзі анықтау мәселелерінің көпшілігі негізінен ғылыми басқару құралы емес, көбінесе объект ретінде қаралатын кәсіптік бағдарлау шеңберінде зерттеледі. Жұмыс мақсаты - кәсіптік бағдар беру жұмысының маңызды жетіспеушілігі - орта мектептің оқушысының жеке қасиеттерін ескермей, мамандық таңдаудың жалпыланған үлгісін пайдалану, кәсіптік өзін-өзі анықтауға дайындықтың әртүрлі деңгейі бар студенттерге сараланған көзқарастың дамытуы болып табылады.

Бұл жұмыс жоғары сынып оқушыларының кәсіби өзін-өзі анықтауына жобаны басқару моделін әзірлеуді қажеттілік туғызады. Зерттеу орта мектептің оқушылары үшін белсенді жобалық жұмысын қарастырады, сондай-ақ түлектер үшін қысқа мерзімді тәжірибеден өту және кәсіпорын жұмыс барысымен танысу мақсатымен сол кәсіпорынға бару мүмкіндігін қарастыруға ұсынады.

Түйін сөздер: кәсіби бағдар, жобаларды басқару, жалпы орта мектептер, мансаптық құрылыс.

Ташпулатов Ш. ${ }^{1}$, Купешова С. ${ }^{2}$, Мейрханова Е. ${ }^{3}$

${ }^{1} \mathrm{PhD}$, Чешский технический университет, Чехия, г. Прага, e-mail: stashpul@cerge-ei.cz ${ }^{2}$ К.э.н., Аоцент, e-mail: s.kupeshova@mail.ru

${ }^{3}$ Аокторант, e-mail: yerkezhan.meirkhanova@gmail.com

2,3Казахский национальный университет имени аль-Фараби, Казахстан, г. Алматы

Практика и модеки формирования

профессиональной ориентации школьников

Проблема безработицы выпускников, неспособность к работе в условиях конкуренции одна из наиболее актуальных проблем современной молодежи. Условия требуют навыков выбора сферы деятельности и построения карьеры, беря в учет и ориентируясь на спрос на рынке труда и осознавая возможности не только материального характера, а также персонального развития, т.е. способности к профессиона^ьной ориентации и построению успешной карьеры в выбранной области. Современная система образования не оказывает существенной подАержки старшеклассникам в профессиональной ориентации, т. к. нет точного определения и определенных составляющих профессиональной ориентации как цели, не в полной мере составлены научнопедагогические теории, адаптированные для современных общеобразовательных школ, и, как следствие, отсутствует системный и проектный подход Аля повсеместного внеАрения подобных знаний и профессиональной ориентации.

Профессиональное самоопределение чаще всего рассматривается в качестве объекта, а не средства научного управления. Целью работы является анализ моделей выбора профессии с учетом индивидуальных особенностей выпускников, дифференцированного метода к разным ученикам с разным уровнем интемлекта и способности профессионального самоопределения, информированности о современных профессиях. Аанные условия определяют необходимость в разработке практической модели проектного управления Аля внеАрения профессиональной ориентации учеников старших классов.

В ходе исследования была выявлена необходимость в предоставлении возможности применения профессий на практике, что позволяет преАложить более активную проектную деятельность Аля учащихся старших кАассов, а также рассмотрение возможности краткосрочных стажировок или визитов на предприятия Аля учащихся выпускных классов.

Кмючевые слова: профессиональная ориентация, проектное управление, общеобразовательные школы, построение карьеры.

\section{Introduction}

Etymologically, the word "project" means "thrown forward," that is, in essence, an activity that had been planned for the future. The project approach initially sets a goal, and, if necessary, go beyond the spatial and organizational framework. In this case, a particular case of a management project can be both investment-related activities and the production of social benefits with the participation of the public (Meredith, 1998:215).

In foreign psychology, the category of "psychosocial identity", developed and introduced into scientific circulation by value and competence, otherwise there is a "blurring" of the feeling of one's "self", due to confusion, doubts about the possibility of directing one's life in a certain direction (Ericsson, 1996:157).

Today, schools use a variety of unsystematic, disordered activities, which are an integral part of the information model of professional determination. These activities are aimed at exploring various aspects of career guidance, for example, becoming familiar with modern types of professions, measures to assess the professional suitability of a student for a particular work, classes aimed at the student's self- 
determination. But do these activities correspond to the expectations and needs of modern school children?

\section{Literature review}

Education system innovations and creativity are important to govern economies (Kulibayeva, 2007). Wolbers (2011) analyzed the way graduates enter into labor market in European countries. Author states that decision-making is different among Europe because labor market differences such as unemployment rate and job nature. Also, Wolbers considered law system and characteristics of professional determination system taking into consideration economic circumstances of countries as important predictors of labor market entries. Based on that research we collected primary data and analyzed it.

Moreover, as qualitative secondary research methods following approaches to professional determination had been considered: Project activity by American philosopher and teacher J. Dewey interpreted by Habib (2014) had been suggested as a learning on an active basis through the student's expedient activity, given his personal interest in this sphere precisely. The project method seems to us to be an effective tool in the career guidance activities of a teacher in high school.

Also, psychological methods of Klimov (1995) whose approach is based on identification of a person's interest in certain types of professions was applied.

An empirical evidence of Russian schools interpreted by Danilyuk (2014). This method helps to form the ability to work with large volumes of information, the ability to work in team and to get familiar with professions. The lesson material was considered according to the following criterias: social needs and the world of professions, professional requirements and labor market competition, motives for choosing a profession, features of social and human science professions, professions descriptions: political scientist, sociologist, psychologist, social teacher.

Azbel (2005) modification method - a testgame "structure of a profession" is viewed as an informational source for graduates who are making choice and make them familiar with the nature of the jobs. Through games it is possible to increase the awareness of professional self-determination of adolescents, expand understanding of the world of existing professions, contribute to the formation of the image of an ideal job for yourself and the creation of a"formulary" of your profession, contribute to the choice of a profession suitable for a teenager from several possible options of his professional future that exist in a new one.

Vassilyev et al. (2013) suggested competencebased approach and put a stress on necessity in acquiring several of them since one cannot be useful without the other. Research Competence is abilities related to the analysis and assessment of the current social situation. The study of social disciplines involves working with historical sources, referring to different points of view on individual events, develops the ability to analyze, summarize information.

Competence of social choice is the ability associated with the skill of making choices and make decisions in a particular social situation, when confronted with specific social problems. The formation of this competence is possible in the lessons where active forms of student activity are used (for example, lessons - role-playing games, conferences, discussions, seminars, etc.).

Competence of social action is the ability associated with decisions made. This competence allows you to identify specific actions, contributes to the successful adaptation to life situations.

Communicative competence is the ability to interact with other people (including tolerance), especially when solving social problems. In this case, crucial communication skills such as the ability to listen to the interlocutor, to conduct a dialogue, to defend their point of view, etc. are acquired.

Learning competence is the ability associated with the need for further education in a constantly changing world.

\section{Methodology}

There are many types of researches based on the nature and purpose of the research. For example, research method can be divided into categories as primary and secondary research. Primary research aims to receive raw data directly from the source by implementing different tools such as surveys, observations, interviews. Secondary research is a process of obtaining information from already published or publicly available resources. This article will include both methods. It is important to reveal real time data and opinion from target audience through interviews.

The article analyzes the data of a survey of students of grades 8 to 11 of secondary schools in the Almaty to assess the effectiveness of the existing forms and methods of career guidance (Sample size 
$(N)=35)$. The results of the study showed that the problem of inconsistency in the nature and quality of professional orientation work with the needs of students really exists and needs to be resolved immediately.

We formed standardized questionnaires to avoid bias. Interviewing respondents we discovered correlations between different aspects of social circumstances.

Coming back to secondary data we refer to already existing scientists in this area such as Project Activities, personal interests and abilities consideration, structure of a profession, competence based approach and decision-making through taking into account economic circumstances.

\section{Results and discussion}

In order to answer the question about the satisfaction of schoolchildren in professional determination, an online survey of students in grades 8-11 was conducted. The purpose of the survey was to assess the effectiveness of existing forms and methods of professional orientation. 35 people from 4 schools in Almaty took part in the survey.

The survey showed that the overwhelming majority of high school students (95\%) thought about their future professional path. Concerning the meaning of professional determination work, the understanding of the respondents on that issue was divided in the following way: $40 \%$ believe that this is professional diagnostics or "measures to assess a person's professional fitness for a particular type of work" the same proportion of respondents understand it as conducting classes aimed at selfdetermination of a student. Only $20 \%$ of respondents view the meaning of career guidance as acquiring knowledge about up-to-date professions.

The question "Which of the listed activities should be more often carried out in your school?" was asked from respondents. $40 \%$ of high school students answered that they need more work with a psychologist-teacher, $40 \%$ need more Open Days at universities and secondary vocational schools, and $55 \%$ of respondents would like to have internships in the chosen sphere organization. Students more often chose practical side of career guidance. Only a few chose information model events.

When asked about weak sides of professional determination works at school, the overwhelming majority (20 respondents) answered that actions towards determination were rarely held, 8 complained on low effectiveness, and 7 responded stated that actions were superficial (Table 1).
Table 1 - Question: From your point of view what are weak sides of professional determination works in your school?

\begin{tabular}{|l|l|}
\hline Rarity of activities & $57 \%$ \\
\hline Do not help to make choice & $23 \%$ \\
\hline Activities are superficial & $20 \%$ \\
\hline Note - compiled by authors based on survey \\
\hline
\end{tabular}

Having lack of information about the situation in the labor market, an approximate knowledge of the future profession did not allow students to answer the question about their professional selfdetermination confidently. Only $8 \%$ accurately determined their future profession.

The small number of students who have precisely defined their future profession allows us to conclude that the information that prevails in schools today is inefficient, and the activities carried out within the framework of that model are obsolete.

Previously, students had enough of their own knowledge, advice of parents and teachers, experience of their friends and relatives to choose a profession, and now it is important to tell them about all the possibilities and prospects for further career building under the diversity of professions. At the same time, modern children need everything "to try on", that is, it is important for them to familiarize themselves with its demo version before making a final decision.

Therefore, it is necessary to actively introduce a new practice-oriented model into schools, which will make it possible to link the theoretical knowledge of students with practical experience.

Factors affecting choice

First of all, it is necessary to focus on the main factors of choice - "want", "can" and "need". The "want" factor assume an awareness of one's interests and their difference from aptitudes. Interest is the desire to study a subject, that is, desire to know. Aptitude is a tendency to engage in a certain activity, i.e. desire to do. Both interests and inclinations can become professional if schoolchildren are included in their personal life plans.

The "want" factor is the most difficult for teenagers to be perceived, and not only the content side of the activity can be behind the desire to do something. This activity can be a means of communication with friends, a means of achieving popularity, increasing self-esteem, etc. And this again concerns, first of all, eighth grade students, for whom communication is still the leading activity. Lack of consideration of this factor gives a large 
number of errors in the choice of profession and can lead to a change of profession in the long run.

The "can" factor implies an understanding of one's abilities and individual personality traits, as well as an assessment of the possibilities of their realization, including training, for example, in a particular city or region. Adults should support and encourage the tendencies of adolescents to do any kind of activity, because during the activities, especially in educational and project activities, they will be able to understand and feel some of their abilities and inabilities of others that need to be developed.

The "must" factor is taken into account to a greater extent than the previous ones, in particular, in concern with the demanded and prestigious. However, the market needs for certain specialists and the prospect of its development within the region are not always taken into account. Finally, it is necessary to take into account social, economic and medical circumstances and limitations.

\section{Choice immaturity}

The question of the possibility to make an independent informed decision on their own choice arises. Leontiev (1989) believes that school graduates are not ready to make a full-fledged choice due to inconsistency of planning function by the age of 16-17. It continues to develop even after the age of 20. However, practice shows that with the skilled support of students' professional self-determination, many of them can successfully cope with this task.

Successful choice of profession by high school students, is characterized by some necessary qualities, namely awareness, independence and responsibility of decision making.

Project Management approach in theory

Project is usually represented as a set of simultaneous and pitched actions which collectively produce an outcome. The main parts of project management are planning, executing, and monitoring collective actions. In majority of research planning approaches, such as a network method, actions are described and identified. The only thing that is needed to be done is scheduling. It is assumed that humans are able to plan the most optimal network of activities. In artificial intelligence science, "planning" states for the sequence of activities, and "scheduling" states for identifying the allocation of resources to accomplish activities (Russell, 1995:10).

Professional determination projects through in practice

There are several approaches to professional determination that can be applied as project management techniques that we would like to put a stress on.

Schoolchildren's Project Activity (SPA) is a form of schoolchildren's educational and cognitive activity, consisting of motivational achievement of the consciously set goal of project creation. It ensures the unity and continuity of different aspects of the learning process and is a means of personality development.

The projects method was established in the $20 \mathrm{~s}$ of the twentieth century in the United States. The ideas of the project activity were developed by the American philosopher and teacher J. Dewey and his student Kilpatrick intended to build learning on an active basis through the student's expedient activity, given his personal interest in this sphere precisely. It is important to show children that their personal interests in the acquired knowledge can and should be useful to them in life. Content for such work must be taken from real life. It should be familiar and meaningful for the learner (Habib, 2014: 803).

Through project activities it is possible not only to get a sum of knowledge, but also to put it into practice. Therefore, SPA is close to trying on the demo-version of particular profession (Figure 1).

Klimov's, Holland's and Azbel's techniques.

Techniques included into the program can logically be divided into several parts. Techniques which are aimed at helping students in professional self-determination - the method of Klimov (1996), which are designed to identify a person's interest in certain types of professions (person - nature; person - equipment; person person; person - sign technique, sign image; person - artistic image).

Method of Holland is aimed at testing the professional orientation, Azbel A.A. modification method is a test-game "structure of a profession," developed on the basis of a four-tier classification of professions by Klimov. The objectives of the test game are to introduces the adolescent with the idea of the existence of common structural components of any profession.

\section{Examples of several schools in Russia}

The school prepares the student to choose a profession using a variety of methods (design training, pre-profile courses, excursions to enterprises, etc.). So, when studying the topic "Activities in the social and humanitarian sphere" in the course of social studies in the tenth grade of the humanitarian profile, the students were set a goal: to get familiar with the professions of the humanitarian profile by interviewing. 


\begin{tabular}{|c|c|c|}
\cline { 3 - 3 } $\begin{array}{c}\text { Testing early professional determination } \\
\text { (with the use of methods listed) under } \\
\text { psychologist observation }\end{array}$ & Who are you? & Evaluation of the project by coordinator \\
\hline $\begin{array}{c}\text { Construction future profession 'formula' } \\
\text { with psychologyst }\end{array}$ & $\begin{array}{c}\text { Creationlcorrection of the project } \\
\text { (individual or team) jointly with } \\
\text { scientific coordinator }\end{array}$ & Archiving of the project into Data base \\
\hline & $\begin{array}{c}\text { Correction of the formula if necessary } \\
\text { (in terms of 'want-can-have to') }\end{array}$ & Starting-upstudent'sportfolio \\
\hline
\end{tabular}

Figure 1 - «Choose a profession - create a project» module implementation in grades 8-10 Source: Habib, 2014: 806

\section{Competence-based approach}

Vasiliev and Goncharevich, on the other hand, came to the conclusion that in order to make the right choice, student must possess a number of competencies. In this sense, social science has great opportunities for its formation as an academic discipline. Each of them is held by a specific set of abilities that make up this competence.

We provided control quizzes before and after the introduction of the competence-based of teaching. The data presented in Table 2.

Table 2 - Comparative analysis of the quality of knowledge and student performance (Primary data)

\begin{tabular}{|c|c|c|}
\hline & $\begin{array}{c}\text { Before } \\
\text { competence-based } \\
\text { approach was } \\
\text { implemented }\end{array}$ & $\begin{array}{l}\text { After competence- } \\
\text { based approach } \\
\text { was implemented }\end{array}$ \\
\hline $\begin{array}{l}\text { The quality of } \\
\text { knowledge }\end{array}$ & $57,30 \%$ & $67,90 \%$ \\
\hline Marks & $98 \%$ & $100 \%$ \\
\hline
\end{tabular}

Thus, the introduction of a competence-based approach to the educational process contributes to an increase in student performance and affects the quality of the knowledge they receive, which will further contribute to more effective selfdetermination, both personally and professionally.

\section{Conclusion}

In this article we considered widest and most spread professional-determination practices. While working with schools we saw the necessity combination of several of them. We also see that professional determination is systematically and closely related to the whole educational school work. It is integral part of the whole educational work and occupies an important place in school curricula and educational programs, and extracurricular work.

All of the works mentioned can be valued as tools to professional orientation, which are clear, standardized and also, widely used. However, through research in our article we realized, that theoretical approach is less naturally valid, consequently, less useful. Most of papers mentioned are useful, but not that effective because they suffer from lack of empirical view. That is why we put a stress on one main approach from literature review and one that we came up with ourselves. The most desired and expectedly successful Project activity by J. Dewey, as well as short-term internships or entity visits for graduates as a result of questionnaires.

Both of these tools can be used in a module format during holidays and student vacations. SPA can be provided in a competition format, that can motivate graduates' interest within the schools. As for mass internships and visits, this is a matter of entities negotiation, where governmental support is crucial. Probably, this is a matter of exchange for some governmental benefits to business that will cooperate or based on non-payed help of graduates only.

Current paper is a tool for school administration to some extent, however, it is provided more with municipal purpose to be used and applied on governmental level for decision-makers.

The main content of career guidance work with elder students is the work on the formation of a conscious choice development of professionally significant qualities, active personal position in the choice of profession. It is necessary to develop a dynamic model for the development of professional self-determination for senior schoolchildren. 


\section{References}

1 Азбель А. Статусы профессиональной идентичности (Опросник) // Практические подсказки психолога. - 2005, c. 23 .

2 Данилюк О., Шайдурова В. Подготовка учеников к выбору профессии // Проекты молодежи: мнение эксперта. 2014. - №1, c. 150.

3 Dow J.C.R., Dicks-Mireaux L.A. The Excess Demand for Labour, A Study of Conditions in Britain, 1946-56 // Oxford Economic Papers. - 1958, p. 10.

4 Ericsson E. Identity: Youth and Crisis, 2nd edition. - 1996, p. 157.

5 Habib M., Fardoun A., Almalaise A. New Teaching Methods: Merging "John Dewey" and "William Heard Kilpatrick" Teaching Techniques / Proceedings of the Federated Conference on Computer Science and Information Systems. - 2014, pp. 803808 .

6 Meredith J.R., Mantel S.J. Project Management: A Managerial Approach. - 1998. - 8th Edition, p. 215.

7 Кулибаева Д.Н. Методологические основы управления профессионально-ориентированным образованием в школах международного типа: Диссертация доктора педагогических наук. - 2007.

8 Климов Е. Психология профессионального самоопределения. - М.: Издательство Феникс, 1996.

9 Климов Е. Образ мира в разнотипных профессиях // Вестник МГУ. - 1995. - №1, с. 224.

10 Леонтьев А. Личность: человек в мире и мир в человеке // Вопросы психологии. - 1989. - №3, С.11-21.

11 Онипко А.А. Проблемы самоопределения старшеклассников при выборе профессии: социологический анализ // В лаборатории ученого. - 2011, с. 192.

12 Smith R.P., Eppinger S.D. Identifying Controlling Features of Engineering Design Iteration // Management Science. 1997. - vol. 43. - no 3, p. 12.

13 Russell S.J., Norvig P. Artificial Intelligence: A Modern Approach (3rd Edition). - 2009, pp. 10-15.

14 Васильев А., Гончаревич Н. Педагогическая поддержка профессиональной ориентации // Вестник Сибирского Государственного Университета. - 2013, с. 3.

15 Wolbers M.H. Patterns of labor market entry: a comparative perspective on school-to-work transitions in 11 European countries // Actasociologica. - 2011. - vol. 50(3), pp. 189-210.

\section{References}

1 Azbel A. (2005) Statusi professional'noi identichnosti (Oprosnik) [Professional determination statuses (Questionnarie)]. Prakticheskie podskazki psikhologa, p. 23.

2 Danilyuk O., Shaydurova V. (2014) Podgotovka uchenikov k viboru professiy [Preparation of students to make professional choice]. Proekti molodeji: mneniye experta, №1, p. 150.

3 Dow J.C.R., Dicks-Mireaux L.A. (1958) The Excess Demand for Labour, A Study of Conditions in Britain, 1946-56. Oxford Economic Papers, p. 10.

4 Ericsson E. (1996) Identity: Youth and Crisis, 2nd edition, p. 157.

5 Habib M., Fardoun A., Almalaise A. (2014) New Teaching Methods: Merging "John Dewey" and "William Heard Kilpatrick" Teaching Techniques. Proceedings of the Federated Conference on Computer Science and Information Systems, pp. 803-808

6 Klimov E. (1995) Obraz mira v raznotipnikh professiyakh [The image of the world in different types of professions: Tutorial]. Vestnik MGU, p. 224.

7 Klimov E. (1996) Psikhologiya professionalnogo samoopredeleniya [Psychology of professional self-determination]. Publishing house "Phoenix", p. 512.

8 Kulibayeva D.N. (2007) Metodologicheskiye osnovi upravleniya professionalno-orientirovannim obrazovaniyem v shkolakh mezhdunarodnogo tipa [Methodological basis of management of professionally oriented education systems of international types of school]. Dissertaciya doktora pedagogicheskikh nauk.

9 Leontiev A. (1989) Lichnost': chelovek v mire I mir v cheloveke [Personality: human in the world and a world in a human]. Voprosi Psikhologii, vol. 3, pp. 11-21.

10 Meredith J.R., Mantel S.J. (1998) Project Management: A Managerial Approach, 8th Edition, p. 215.

11 Onipko A.A. (2011) Problemi samoopredeleniya starsheklassnikov pri vibore professii: sociologicheskiy analiz [Self-determination of high school students in the choice of profession: sociological analysis]. V laboratorii uchenogo, p. 192

12 Russell S.J., Norvig P. (2009) Artificial Intelligence: A Modern Approach (3rd Edition), pp. 10-15.

13 Smith R.P., Eppinger S.D. (1997) Identifying Controlling Features of Engineering Design Iteration. Management Science, vol. 43, no 3, p. 12.

14 Vassilyev A., Goncharevich N. (2013) Pedagogicheskaya podderzhka professionalnoi orientacii [Pedagogical support of the self-determination process]. Vestnik Sibirskogo gosudarstvennogo Universiteta, p. 3.

15 Wolbers M.H. (2011) Patterns of labour market entry: a comparative perspective on school-to-work transitions in 11 European countries. Actasociologica, vol. 50(3), pp. 189-210. 